\title{
Beef and Beyond: Paying for Ecosystem Services on Western US Rangelands
}

\author{
By Joshua H. Goldstein, Carrie K. Presnall, \\ Laura López-Hoffman, Gary P. Nabhan, Richard L. Knight, \\ George B. Ruyle, and Theodore P. Toombs
}

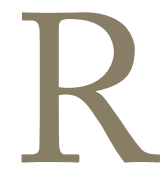

angelands provide a diverse array of vital services that pertain to human life: food and fiber, clean drinking water, climate regulation, recreational experiences, wildlife habitat, and others. ${ }^{1,2}$ With the notable exceptions of food, fiber, and other livestock products, most of these benefits from nature remain largely outside economic markets. For private landowners, mostly ranchers, who steward millions of acres of rangelands across the 17 states in the western United States, income is primarily generated through their livestock and less so from stewardship of the broader set of public benefits. Ranchers and diverse publics have shared interests in these benefits, and ranchers have a financial interest in maintaining the long-term productivity of these landscapes. Still, the lack of economic linkages means that the private financial interests of ranchers (e.g., earning a living) are not necessarily aligned with the public's interest in maintaining and improving ecosystem health.

Every year, an estimated three million acres of private land across the United States are developed and urbanized, ${ }^{3}$ and this nationwide trend is indicative of what is happening to rangelands across the western United States. The pressures facing rangelands are complex and interconnected: population growth, with several of the fastest growing states in the nation in the western United States; conversion of rangelands from extensive livestock operations to intensive farming or exurban housing developments; thin profit margins for livestock operations (although livestock prices, cattle in particular, are relatively high, input costs have also risen substantially); aging rancher demographics driving uncertainty about who will be the future stewards of rangelands; expanding urban demands on natural resources, particularly water transfers from agricultural to urban uses; and many others. Collectively, these pressures highlight what is at stake regarding the lifesustaining and life-fulfilling benefits that rangelands provide to people. Equally important, society should not assume that private ranchers will be able or willing to provide these public benefits in the future without incentives.

Aligning private and public values in land management has long been recognized as a formidable challenge, and rangelands are no exception. Aldo Leopold wrote, "The crux of the problem is that every landowner is the custodian of two interests, not always identical, the public interest and his own" (p. 160). ${ }^{4}$ To address this problem, he continued, "What we need is a positive inducement or reward for the landowner who respects both interests in his actual landpractice" (p.160). ${ }^{4}$ Leopold elsewhere urged for the development of "practicable vehicles to carry that reward," recognizing that these vehicles could take many different approaches. ${ }^{4}$

Here we explore one particular approach, payments for ecosystem services (PES), which is receiving widespread attention and investment across the world. Indeed, it is the active exploration and implementation of PES in rangeland systems and elsewhere that in part motivated the writing of this paper. Our objective here is to define and describe the PES approach and to place it in the context of rangeland systems. More specifically, we address the following questions: What are ecosystem services, and how might PES create incentives for their stewardship? What types of PES programs are currently in operation, and how are they working to better align private and public interests in rangeland management? Who are the buyers, and who are the sellers? What are the strengths and drawbacks of PES, and what issues need to be resolved to determine if PES can be a meaningful "workable vehicle" for rangeland systems? In addressing these questions, our aim is to provide background information and context for the rangelands community. We emphasize at the outset that we are neither advocating for nor against the development of PES programs or market-based approaches more broadly. Furthermore, insofar as the PES approach seeks to assign an economic value to ecosystem services, we acknowledge the importance of ensuring that a wide set of values, including 
but not limited to economic values, are factored into decision making. We invite active discussion in this journal about the PES approach discussed in this paper and the topics raised in the other papers in this special section.

\section{Ecosystem Services from Rangelands}

Ecosystem services are the benefits that people derive from nature that support and fulfill human life. ${ }^{5}$ Although livestock products are likely the most recognized ecosystem service provided by rangelands, healthy rangelands provide a wide array of ecosystem services. ${ }^{1,2,5}$ Drawing upon the four categories defined by the Millennium Ecosystem Assessment, ${ }^{5}$ examples of rangeland ecosystem services include the following: 1) provisioning services (also referred to by others as ecosystem goods), such as animal protein, clean drinking water, and timber; 2) regulating services, such as processes by which rangelands help to sequester carbon (contributing to climate regulation) or purify water that passes through them; 3) cultural services, such as outdoor recreation, hunting, wildlife viewing, maintenance of traditional lifestyles, and spiritual fulfillment; and 4) supporting services that are needed to support the production of services in the preceding three categories, such as nutrient cycling, soil formation, and net primary production. Table 1 provides an expanded list of rangeland ecosystem services. The Millennium Ecosystem Assessment reported that, globally, approximately 63\% (15 of 24) of examined ecosystem services have been widely degraded or used unsustainably, to the degree that their capacity to deliver ecological, economic, and health benefits to humans has been reduced. ${ }^{5}$ This situation heightens the importance of maintaining ecosystem services provided by the remaining areas, especially large working landscapes, as well as restoring ecosystem services on degraded lands.

Growing awareness of the value of ecosystem services to society, as well as the factors threatening their continued provision, is catalyzing a new paradigm-viewing ecosystems as capital assets, which, if managed correctly, will provide a stream of environmental benefits (as well as a source of income) today and into the future. To motivate this concept, consider, for illustrative purposes, the situation of a working ranch. From an economic perspective, the land's primary year-by-year financial value comes from livestock grazing and the many products that result from it (and over a longer time horizon, land value appreciation is also important). Although food and other marketable commodities are important factors driving rangeland management, these lands supply additional benefits to society (e.g., wildlife habitat, soil formation, carbon sequestration, and water quality improvements), as discussed above. Historically, these nonextractive benefits have not had values recognized by economic markets, although the Farm Bill and other publicly funded programs have provided incentives to landowners. Recognizing that there are "missing markets" for many ecosystem services that are integral to the public good (as environmental economists often point out), ${ }^{6}$ leaders across the public, private, nonprofit, and academic sectors are working together to develop new financial and institutional mechanisms to better align private and public needs in land management.

\section{What Are Payments for Ecosystem Services?}

Payments for ecosystem services are a market-based approach in which users of ecosystem services directly compensate providers (meaning landowners) for supplying services (Fig. 1). PES creates an economic feedback loop between users and providers where a missing market existed previously. PES combines a positive incentive ("if you improve and protect a resource, you can get paid by others to do so") with a negative incentive ("if you impact a resource, you must or should pay for it"). In addition to public funding for conservation, PES extends the responsibility to individuals and private sector entities to pay for resources that they depend upon or impact. In concept, PES targets payment for measured outcomes (e.g., tons of carbon dioxide sequestered or phosphorous runoff reduced) rather than practices (e.g., installing a fence to protect a waterway). In existing PES programs, however, payments may be either practice or outcome based, though generally with the intention of shifting over time to paying for measured outcomes. This approach is analogous to being paid for pounds of beef, rather than being paid for installing fences to manage cattle that results in pounds of beef.

Based upon market research, Forest Trends and the Ecosystem Marketplace, two organizations actively involved with PES programs around the world, published a report in 2008 titled "Payments for Ecosystem Services: Market Profiles." This report provided two complementary ways to categorize the growing number of PES programs globally: first, by the type of ecosystem service, and second, by the payment type.

In terms of ecosystem service types, the report defined four categories. ${ }^{7}$ First are carbon-focused payment programs, which provide payments to landowners for undertaking practices that enhance (or avoid the loss of) vegetative and soil carbon stocks, therefore contributing to regulation of the planet's climate. According to a recent report, a minimum of $\$ 149.2$ million has been transacted to date for forest carbon offset credits, with the larger set of carbon markets (e.g., European Union Emissions Trading System) trading in the billions of dollars. ${ }^{8}$ Second are water-focused payment programs, which provide payments to landowners for stewarding attributes of water resources related to water quality, quantity, location, and timing. The value of payment projects focusing specifically on water quality was recently estimated to be $\$ 9.3$ billion in 2008 , and $\$ 50$ billion across all years that examined programs have been active. ${ }^{9}$ Third are biodiversity-focused payment programs, which provide payments to landowners for undertaking practices that result in the protection and enhancement of habitat and target species, including mitigation banks for protecting the habitat of endangered species. According to a recent report, ${ }^{10}$ mitigation banks exist to protect the habitat of at least 119 species in the United States, with a rougher estimate of at least 600 banks operating 


\begin{tabular}{|c|c|c|}
\hline Ecosystem service & Definition & Examples \\
\hline \multicolumn{3}{|l|}{ Provisioning } \\
\hline \multicolumn{3}{|l|}{ Food } \\
\hline Crops & $\begin{array}{l}\text { Plants cultivated for humans or managed } \\
\text { animals }\end{array}$ & Hay, alfalfa, corn \\
\hline Livestock & Animals raised for consumption & Cattle, sheep \\
\hline Wild foods & $\begin{array}{l}\text { Edible plants or animals harvested from the } \\
\text { wild }\end{array}$ & Elk, deer, antelope \\
\hline \multicolumn{3}{|l|}{ Fiber } \\
\hline Wood-based & Products made from harvested trees & Firewood \\
\hline Other fibers & Products made from nonwood fibers & Leather, wool \\
\hline \multicolumn{3}{|l|}{ Regulating } \\
\hline Air quality & $\begin{array}{l}\text { Emitting or extracting chemicals from } \\
\text { atmosphere }\end{array}$ & Fire emits particulates \\
\hline $\begin{array}{l}\text { Carbon sequestration } \\
\text { (climate regulation) }\end{array}$ & Influence of rangelands on global climate & $\begin{array}{l}\text { Grasses and soils capture carbon } \\
\text { dioxide }\end{array}$ \\
\hline Water regulation & $\begin{array}{l}\text { Timing and magnitude of water runoff, } \\
\text { flooding, recharge, etc. }\end{array}$ & Playa lakes recharge aquifers \\
\hline Water purification & $\begin{array}{l}\text { Filtering pollution, decomposition of waste, } \\
\text { etc. }\end{array}$ & Wetlands filter waste \\
\hline Erosion regulation & Role vegetation cover plays in soil retention & Grass prevents soil loss \\
\hline Disease regulation & $\begin{array}{l}\text { Role of rangelands on incidence of } \\
\text { pathogens }\end{array}$ & Control of mosquitoes \\
\hline Crop pollination & $\begin{array}{l}\text { Transferring pollen from female to male } \\
\text { flowers }\end{array}$ & Bees pollinate nearby crops \\
\hline Pest regulation & Role of ecosystems in prevalence of pests & Bats consume bugs \\
\hline Natural hazard regulation & Reducing damage from natural disasters & Vegetation reduces flood damage \\
\hline \multicolumn{3}{|l|}{ Cultural } \\
\hline Recreation & Pleasure derived from outdoor activities & Hunting, bird watching \\
\hline $\begin{array}{l}\text { Aesthetic and spiritual } \\
\text { values }\end{array}$ & Inspiration derived from nature & Sense of awe, viewsheds \\
\hline $\begin{array}{l}\text { Maintenance of traditional } \\
\text { lifestyles }\end{array}$ & $\begin{array}{l}\text { Role of ecosystems in supporting traditional } \\
\text { ranching activities }\end{array}$ & $\begin{array}{l}\text { Ranch livestock and stewardship } \\
\text { activities }\end{array}$ \\
\hline Research and education & Role ecosystems play in learning & Rangeland research projects \\
\hline \multicolumn{3}{|l|}{ Supporting } \\
\hline Nutrient cycling & $\begin{array}{l}\text { Role of ecosystems in nutrient flow and } \\
\text { recycling }\end{array}$ & $\begin{array}{l}\text { Decomposition of organic matter } \\
\text { contributes to fertility }\end{array}$ \\
\hline Primary production & $\begin{array}{l}\text { Formation of biological material by plants } \\
\text { through photosynthesis }\end{array}$ & Algae in wetlands \\
\hline Water cycling & Flow of water through ecosystems & $\begin{array}{l}\text { Transfer of water from soil to plants to air, } \\
\text { and air to rain }\end{array}$ \\
\hline
\end{tabular}

globally. Financial information was available for only about one-fifth of these banks, but a lower-bound estimate of the financial value of these markets is $\$ 1.8$ to $\$ 2.9$ billion annually. ${ }^{10}$ Fourth are bundled payments, which secure all or a combination of carbon, water, and biodiversity benefits. Examples include eco-certified products such as beef, timber, and coffee, in which protection of ecosystem services is considered to be embedded in the products through improved management practices.

In terms of payment types, there are three categories. ${ }^{7}$ First are compliance markets, which are created by regulation (e.g., the Endangered Species Act, Clean Water Act). Second 


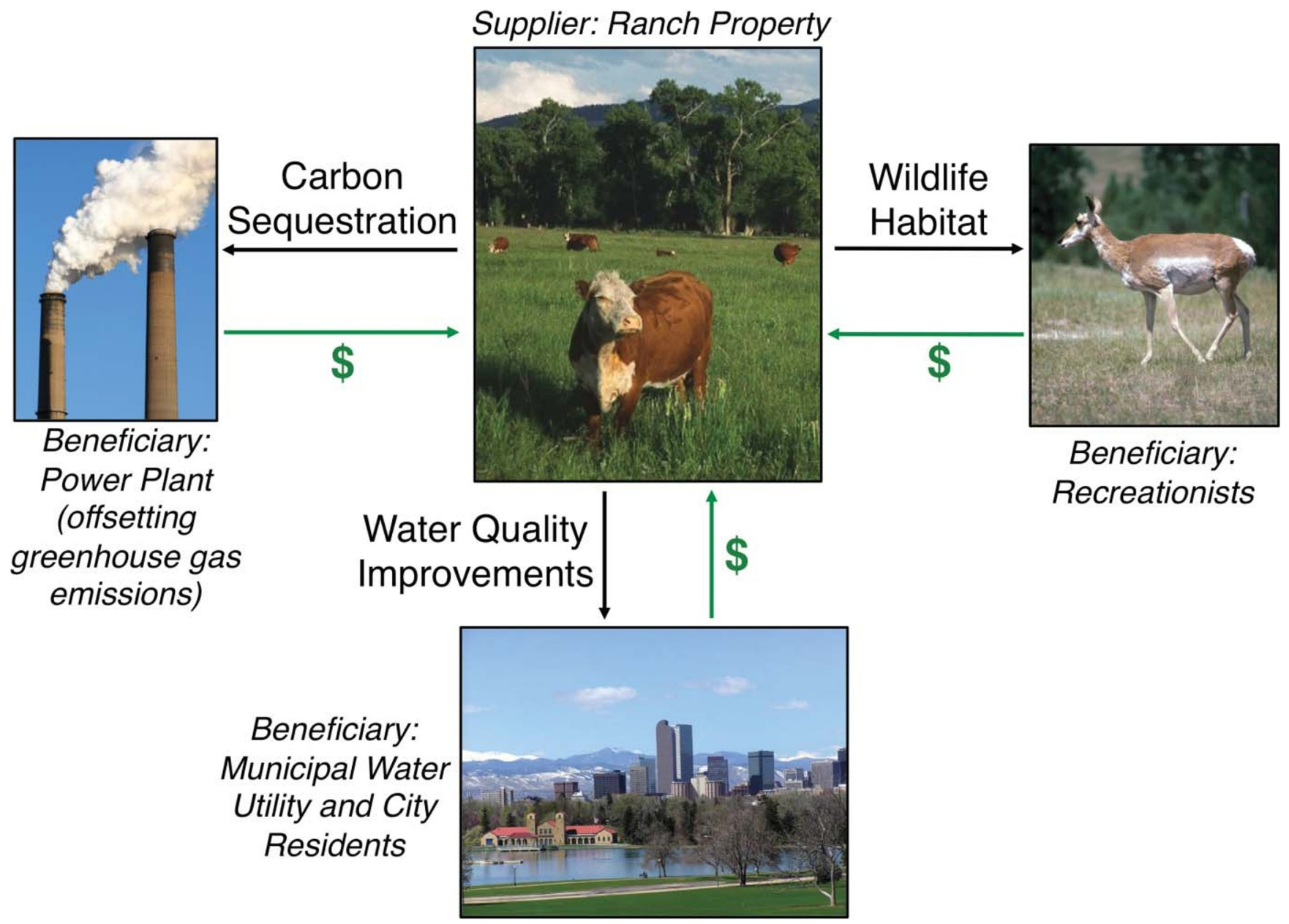

Figure 1. Payments for ecosystem services establish an economic feedback loop between suppliers and beneficiaries of ecosystem services. In this illustrative example, a rancher managing a livestock operation provides benefits "outward" to society related to carbon sequestration, water quality improvements, and wildlife habitat. In return, the landowner receives compensation from public and private sector users: a power plant to offset greenhouse gas emissions through carbon sequestration, municipal water utility and city residents for water quality improvements, and recreationists for wildlife viewing opportunities. Photo credits: Pixel Perfect Digital, Inc. (top left); Gary Kramer, USDA NRCS (top middle; cropped from the original); James C. Leupold, USFWS (top right; cropped from the original); Photobucket Corporation (bottom).

are voluntary markets, which motivate payments for value- and business-driven reasons. Third are government-mediated payment programs (e.g., Farm Bill programs), in which public funds are used to pay landowners for protecting or enhancing ecosystem services. Although the report, "Payments for Ecosystem Services: Market Profiles," included public payment programs that are not specifically markets as a form of PES, we note that others prefer a more narrow definition that is specific to only market-driven PES.

Recalling the illustrative working ranch discussed above, we noted that this ranch supplies an array of valuable, yet generally uncompensated for, ecosystem services to society such as wildlife habitat, soil formation, carbon sequestration, and water quality improvements. PES establishes a revenue stream, paid for by users and received by landowners, to help ensure that there is an incentive for these services to continue to be supplied in the future. For example, a residential developer might pay a landowner to protect habitat for an endangered species through a species mitigation bank to offset the impacts of a new housing development built elsewhere; a power plant might pay a landowner to enhance carbon sequestration on his or her land to partially offset the plant's greenhouse gas emissions; and a bottling company might pay a landowner to reduce nutrient loading into a stream to protect water quality. We acknowledge upfront that such approaches are far from mainstream and face many challenges for success (see below). Yet, as noted above, real dollars are flowing from buyers to sellers, and stakeholders are currently testing how to make the PES concept operational.

\section{Selling Ecosystem Services}

To provide insight into the range of contexts being addressed by PES programs, we briefly describe three existing projects involving ranchers and other landowners. First, in the northern Everglades region of Florida, ranchers are receiving 
payments through the Florida Ranchlands Environmental Services Project (FRESP) to provide ecosystem services related to water storage and nutrient retention. ${ }^{11, i}$ Through FRESP, state agencies are exploring a more cost-effective way to address regulatory requirements by paying ranchers, who sign voluntary, fixed-term contracts, to enhance ecosystem services on their property. These payments can provide support to ranch operations, which are challenged by thin profit margins and pressure to convert to more intensified agriculture or to sell land for development, both of which decrease water storage capacity and increase nutrient runoff impacting downstream waterways. As this project develops, a key goal is to pay ranchers for measured ecosystem service outcomes (e.g., enhanced nutrient retention) rather than the more traditional approach of providing cost-share assistance for prescribed practices.

Second, in Texas, a recovery credits system was recently pilot-tested for the endangered Golden-cheeked Warbler (Dendroica chrysoparia). ${ }^{\text {ii }}$ Through this system, private landowners are paid to implement management and conservation practices benefiting the warbler on their property as an offset (involving a net benefit to the species) for impacts from US Army maneuvers at the adjacent Fort Hood military base. In doing so, investments made by the Army in improving habitat on private lands will contribute to recovery efforts for this federally listed species. Landowners bid to participate in this system through a reverse auction process designed to maximize the conservation cost effectiveness of the Army's investment. This program involves collaboration between a diverse range of stakeholders, including the US Army, Texas Watershed Management Association, Texas A\&M University, Texas Parks and Wildlife Department, US Department of Agriculture, US Department of Interior, and Environmental Defense Fund.

Last, in the Willamette Basin in Oregon, the Willamette Partnership has launched a multicredit ecosystem services marketplace. iii Through this marketplace, landowners are able to sell four types of ecosystem service credits: wetlands, salmon habitat, upland prairie habitat, and water temperature regulation. For buyers (e.g., utilities, corporations), the marketplace provides a streamlined source for addressing mitigation and other environmental needs, while also ensuring that investment from different entities contributes effectively to regional conservation targets.

These programs, from Florida to Texas to Oregon and elsewhere, are united by a set of common features: first, positioning landowners to sell ecosystem service "commodities" (e.g., nutrient retention or Golden-cheeked Warbler habitat) that have never before been marketable in a mainstream

'For more information on the Florida Ranchlands Environmental Services Project, see http://fresp.org.

iiFor more information on the Golden-cheeked Warbler recovery credits system, see http://rcs.tamu.edu.

iii For more information on the Willamette Partnership, see http:// willamettepartnership.org. way; second, enlisting public and private sector buyers to pay for ecosystem service benefits that they have previously obtained largely for free; and, third, using market-based approaches to connect buyers and sellers through new contractual arrangements that drive investment in good land stewardship - for the benefit of landowners and diverse publics.

For ranchers, PES creates the possibility of new revenue streams and a more diversified business model in which ranchers are compensated not only for their livestock products, but also for the broader range of ecosystem service benefits supplied through their land stewardship. As Toombs et al. (this issue) discuss, a ranch-level ecosystem services inventory can provide a way for ranchers to more effectively manage risks (e.g., harboring endangered species) and capitalize on opportunities (e.g., marketing ecosystem service credits) to help create a more diversified and robust ranch business model. Although many ranchers are already employing practices that lead to multiple ecosystem service benefits, the key difference would be the existence of tangible market-based structures that financially reward ranchers for being in the "business" of selling ecosystem services. However, under current conditions, these rewards may not equal the income generated from livestock production, so they may best be considered supplemental rather than primary revenue streams.

In examining what PES may mean for ranch business models in the future, it is important to acknowledge the many important publicly funded programs through which ranchers are already being compensated for ecosystem services. Examples include USDA Farm Bill programs and a variety of tax incentives (particularly for conservation easements). For example, a recent study in Colorado determined that the 1.41 million acres placed in conservation easements at a cost of $\$ 595$ million have returned $\$ 3.51$ billion dollars in public benefits, based on the ecosystem services maintained by these lands staying in productive range and forest uses. ${ }^{12}$ That is, for every dollar invested in keeping private range and forest lands out of development and in production, citizens of Colorado received a $\$ 6$ return in ecosystem services on this public investment. The return on these investments will likely continue to grow over time as undeveloped lands capable of producing ecosystem services continue to diminish in the face of ongoing exurban and commercial development. Since existing public programs have been explored at length elsewhere, we do not further discuss them here. These programs are likely to remain important funding sources to protect and restore ecosystem services on private lands.

\section{Rangeland Ecosystem Services for Sale ... Are There Buyers?}

As noted above, there are increasingly large dollar flows in PES programs globally. Although we know of no estimate solely for rangeland PES programs, it is safe to say that such dollar flows are a small fraction of the total, because rangeland systems have not been the focus of many PES 
programs to date. ${ }^{13}$ As such, the question arises: Who should buy rangeland ecosystem services, and why? We discuss opportunities in two currently active areas: first, mechanisms that allow buyers to pay directly for rangeland ecosystem services; and, second, mechanisms that allow buyers to pay for rangeland ecosystem services that are embedded in livestock (or other ranch) products.

The projects described above in Florida, Texas, and Oregon are all examples of programs in which public and private sector buyers are paying directly for ecosystem service credits. Creating direct contractual links between buyers and sellers is the primary concept driving the PES approach to ensure a greater accountability for delivery of the purchased ecosystem services. Three general buyer groups are active in direct PES programs, each of which we see as playing an important role in rangeland contexts. The first group is public agencies, and particularly municipal utilities, who need to meet water quality and other regulatory targets, as well as who see strategic opportunities for PES programs to manage the risks and costs associated with utility supply. For example, Denver Water, which serves the city of Denver, Colorado, and surrounding suburbs, recently entered into a five-year, $\$ 33$ million partnership with the US Forest Service to fund forest health treatments aiming to reduce wildfire and other watershed risks that affect the utility's water supply infrastructure. ${ }^{14}$ The second group of buyers is the private sector, particularly corporations focused on advancing corporate social responsibility, cost-effectively meeting regulatory targets, or proactively managing ecosystem risks that affect the company's bottom line. ${ }^{15}$ The final group of buyers is consumers, who can voluntarily choose to offset their environmental impacts or otherwise fund conservation efforts for personal reasons. Carbon offsets are an important example of this activity. For rangelands in the United States, however, the situation is in flux because of the closure of the Chicago Climate Exchange in 2010, which had an offset program titled the Sustainably Managed Rangeland Soil Carbon Sequestration Offset Project (Gosnell et al., this issue). Furthermore, a national policy regulating greenhouse gas emissions has not yet emerged, meaning that there is no federal regulatory driver for a national carbon offset payment program. Some states have passed regulations, which include opportunities for landowners to sell carbon offset credits from rangelands and other land uses. Increasingly, carbon payments are being complemented by efforts related to water quality, water quantity, and biodiversity protection. Currently, for ranchers in any particular region across the West, opportunities are likely limited, if present at all, to participate in direct, market-based PES programs, which we differentiate as the newer opportunity presented by PES (in contrast, Farm Bill programs will be more widely accessible). If direct PES programs are to be advanced, it will be critical to simultaneously engage demand- and supply-side stakeholders to identify strategic areas for PES development.

Recognizing the limited implementation to date of direct PES programs in rangeland systems, another avenue for ranchers to be compensated for ecosystem services is by embedding the value of these services in livestock products and other amenities already marketed from rangelands. For example, value-added niche meat products provide ranchers with an opportunity to market the land stewardship benefits, as well as animal husbandry, rancher livelihood, and community values that result from sustainable management practices and meeting product certification standards. We label these approaches as being embedded PES, since the ecosystem service values are incorporated into the marketed product. A few examples of such products include grass-fed, natural, organic, and predator-friendly beef. Buyers of these products include consumers, restaurants, and retailers who are seeking products that they perceive to be of greater quality and contributing to environmental and community values.

Niche meat markets represent one of the fastest growing segments of the overall meat market. For example, between 2002 and 2003, retail sales for this sector grew by $77.8 \%{ }^{16}$ Groups such as Country Natural Beef, Lava Lake Lamb, Tallgrass Beef, and others have adopted stewardship practices (e.g., reducing pesticide use, restoring wildlife habitat, protecting waterways) that contribute to land health and allow for their products to be marketed in a way that differentiates them from the broader commodity market space. Niche markets provide an opportunity for ranchers to connect with consumers who are willing to pay a price premium for the embedded values. While growing fast, these markets remain relatively small and volatile, and they can be difficult for ranchers to transition into. Further work is needed to determine how to make these markets more tenable for risk-averse ranchers.

As an indication of where product-embedded programs may be heading, credits for ecosystem services can be explicitly integrated with food products as they move through the supply chain from landowner to food consumer. For example, IMI Global, a provider of verification programs in the agricultural and livestock sectors, has launched a VerifiedGreenTM program that allows for the quantification and tracking of carbon offset credits associated with production and land stewardship practices for each calf that is brought to market. ${ }^{\text {iv }}$ This type of "PES on the hoof" program takes a direct step toward embedding ecosystem services into traditional products supplied by working lands to enable buyers to be more aware of the impacts of their consumption practices, and for sellers to be compensated for the environmental benefits of the products they supply.

\section{PES: Panacea or Fool's Gold?}

There are growing expectations being placed on PES to better align public conservation and private financial values in land management. That said, experience with PES to date shows importantly that PES is not a silver-bullet solution

iv For more information on the VerifiedGreen program, see http://www. imiglobal.com/Downloads/VerifiedGreen.pdf. 
for all of the ills facing rangelands, the people who manage them, and the people who benefit from livestock products and other rangeland ecosystem services. Rather, opportunities and legitimate concerns are seen about advancing PES that must be critically evaluated in determining the viability-or lack thereof-of PES in rangeland systems. The degree to which these strengths and concerns are realized in any one program depends upon program design and the broader economic, environmental, and political context in which the program operates. Although it is beyond the scope of this paper to provide a comprehensive analysis and critique of the strengths and drawbacks of PES (and market-based approaches more generally), below we briefly highlight several key items for consideration. We refer readers to references cited in this section and throughout the paper for further information.

Practical and theoretical experience with PES suggests multiple potential strengths that could contribute to more sustainable rangeland systems. First, PES may provide access to new, larger, and more diverse funding sources for improved land stewardship (especially from the private sector) than traditional conservation approaches. Accordingly, PES income to ranchers could contribute to livelihood support and more resilient rural economies. We note, however, the fair criticism that has been raised that larger and more capitalized landowners may have better access to financial and human resources to participate in PES, thereby outcompeting other landowners. ${ }^{17}$ Second, having users pay for the ecosystem service benefits they receive from rangelands could create greater awareness of the challenges facing ranchers and the threats to resources that users depend upon. By linking buyers and sellers, an additional positive result could be helping to bridge the increasing divide between urban (primarily buyers) and rural (primarily sellers) communities. In turn, this situation could result in a third benefit of PES, which is to broaden the support base for sustainable rangeland management. Beyond mobilizing urban and rural constituencies, PES has provided a platform for partnerships across the public, private, nonprofit, and academic sectors to find common ground to develop more effective coalitions to support land stewardship. For many existing programs, including the Florida, Texas, and Oregon programs discussed above, this ability to engage a wide range of stakeholders, including some that historically have been at odds with each other, is a potential strength of the ecosystem services approach.

The momentum and resources building behind PES are balanced by serious concerns about the ability of PES to deliver upon its expectations, and more fundamentally whether market-based approaches will compromise rangeland stewardship. ${ }^{18-20}$ First, concerns have been expressed about the inappropriateness of assigning economic values to nature, and relatedly, how PES could lead to the "commodification" of nature. In A Sand County Almanac, Leopold expressed these concerns, which are as relevant today as when Leopold wrote about them: ${ }^{21}$
At the beginning of the century, songbirds were supposed to be disappearing. Ornithologists jumped to the rescue with some distinctly shaky evidence to the effect that insects would eat us up if birds failed to control them. The evidence had to be economic in order to be valid. It is painful to read these circumlocutions today. We have no land ethic yet, but we have at least drawn nearer the point of admitting that birds should continue as a matter of biotic right, regardless of the presence or absence of economic advantage to us. (p. 210-211)

Although PES can assist constructively in recognizing the economic value of ecosystem services to people, there is also the very real risk that assigning an economic value will result in stakeholders considering only these economic values in management and decision making, while ignoring other noneconomic modes of valuation that are also important to consider. If this occurs, then PES may not bring rangeland stakeholders any closer to comprehensive decision making. A related concern is that PES, by assigning an economic value to ecosystem services, could actually justify their degradation if alternative land uses have higher values (e.g., residential development) or if cheaper substitutes to ecosystem services that meet human needs arise in the future (e.g., a cheaper way to treat water at a filtration plant rather than paying ranchers for practices that protect water quality).

Second, markets are known to exhibit boom and bust cycles, and critics argue that it would be irresponsible and ultimately ineffective to put ecosystem service values at risk of liquidation when economic downturns occur. Not surprisingly, this issue is at the forefront of many people's minds given the recent and ongoing global financial crisis. Furthermore, the closing of the Chicago Climate Exchange and its rangeland carbon offset program has not gone unnoticed in the rangeland community (see Gosnell et al., this issue), which may lead to potential PES buyers and sellers being skittish to participate.

Third, who in society will be willing to pay for ecosystem services, and who should pay? We mostly receive ecosystem services for free from nature and thus mostly take these services for granted unless they are degraded. Regulations such as the Endangered Species Act, Clean Water Act, and Clean Air Act were enacted in the 1970s and are still today the major drivers of environmental markets, as they establish the compliance targets that are critical to driving market demand. Voluntary markets are small in comparison and largely driven by consumer preferences and corporate social responsibility. Is there a convincing business case for why corporations concerned about their bottom line should pay for ecosystem services upon which they depend? Will further regulation (local, state, or federal) be needed to expand and scale up PES activity? What role should the public sector play in funding PES programs, and will existing programs (e.g., Farm Bill programs) be modified to become more market based? Answering these and related questions is critical 
to understanding the appropriateness of PES as a tool for protecting ecosystem services.

Fourth, critics are asking whether PES will lead to healthy, resilient ecosystems or whether the current single ecosystem service focus of most PES programs will perpetuate distortions in land management that are not ecologically beneficial. For example, will payments for carbon sequestration incentivize landowners to optimize for carbon-driven income but not address negative impacts (e.g., on water quality or quantity) that may result from management practices targeting enhanced carbon sequestration? This concern gets at a fundamental issue of the degree to which multiple ecosystem services will be co-produced through PES-incentivized land uses and management practices (e.g., practices to enhance carbon sequestration also enhance water quality) versus result in unintended trade-offs (e.g., practices to enhance carbon sequestration lead to impairments in water quality).

Fifth, critics have stated that the rapid growth of PES is occurring in a context where adoption of this approach is outpacing rigorous justification and measurable results. Based upon this concern, Redford and Adams stated that

Conservation has a history of placing great faith in new ideas and approaches that appear to offer dramatic solutions to humanity's chronic disregard for nature (e.g., sustainable development, community conservation, sustainable use, wilderness), only to become disillusioned with them a few years later. (p. 785) ${ }^{19}$

Indeed, we concur that critical examination of PES is needed to determine if PES can deliver upon its promise. ${ }^{22}$

\section{Conclusion}

As experimentation with PES expands in rangeland systems across the United States, it will be important for ranchers, practitioners, researchers, companies, public agencies, and other stakeholders to investigate, collaborate, and critically reflect upon PES design, implementation, and evaluation. Existing programs can inform and expedite the development of new programs; similarly, pilot tests of new approaches are likely to help existing programs become stronger and identify opportunities for expansion. Alongside PES experimentation, it will be necessary to document and evaluate desirable and undesirable outcomes to determine whether the approach is advancing or compromising rangeland sustainability. For everyone involved, questions such as the following must be addressed: Will PES programs actually help society better manage ecosystem services that are integral to human wellbeing? Is it appropriate to "commodify" and price rangeland ecosystem services in the marketplace? What happens if technological substitutes for ecosystem services become cheaper, and therefore the economic argument for ecosystem service protection is removed? Is there a solid scientific basis justifying the ecosystem service benefits that are being paid for? Are landowners in a position to adopt new management practices that will deliver enhanced ecosystem services, and will PES payments lead to more diversified and robust ranch business models? Are there compelling reasons why ecosystem service beneficiaries will step up to pay into a PES program, and who in society should pay? Having an engaged group of stakeholders wrestling with these and other related questions will be critical in determining whether PES programs will prove to be an effective tool in the toolbox for advancing sustainable management of rangeland systems. Critical discussion and reflection in the rangelands community about PES and market-based approaches more generally is essential, and we hope that this paper has constructively provided information to advance this conversation.

\section{Acknowledgments}

We thank the anonymous reviewer and Lori Hidinger for constructive comments that improved the manuscript. Our ideas also benefited greatly from 1) conversations at a retreat on ranching and ecosystem services in Phoenix, AZ, in February 2010, hosted by the Diablo Trust and funded by the Blackstone Ranch Institute, 2) the Ecosystem Markets conference in Raleigh, NC, in June 2010, hosted by the American Forest Foundation and the World Resources Institute, and 3) a Center for Collaborative Conservation workshop on PES held in Fort Collins, CO, in May 2011.

\section{References}

1. Havstad, K. M., D. P. C. Peters, R. Skaggs, J. Brown, B. Bestelmeyer, E. Fredrickson, J. Herrick, and J. Wright. 2008. Ecological services to and from rangelands of the United States. Ecological Economics 64:261-268.

2. SkAGgs, R. 2008. Ecosystem services and western U.S. rangelands. Choices: The Magazine of Food, Farm E Resource Issues 23:37-41.

3. Macie, E. A., and L. A. Hermansen [eds.]. 2002. Human influences on forest ecosystems: the southern wildland-urban interface assessment. Asheville, NC, USA: USDA Forest Service, Southern Research Station. GTR-SRS-55. 159 p.

4. Meine, C. D., and R. L. Knight. 1999. The essential Aldo Leopold: quotations and commentaries. Madison, WI, USA: University of Wisconsin Press. 384 p.

5. Millennium Ecosystem Assessment. 2005. Ecosystems and human well-being: synthesis. Washington, DC, USA: Island Press. 137 p.

6. Stoneham, G., V. Chaudri, A. Ha, and L. Strappazzon. 2003. Auctions for conservation contracts: an empirical examination of Victoria's BushTender trial. Australian Journal of Agricultural and Resource Economics 47:477-500.

7. Forest Trends and the Ecosystem Marketplace. 2008. Payments for ecosystem services: market profiles. Available at: http://ecosystemmarketplace.com/documents/acrobat/PES_ Matrix_Profiles_PROFOR.pdf. Accessed 01 July 2011. 36 p.

8. Hamilton, K., U. Chokkalingam, and M. Bendana. 2010. State of the forest carbon markets 2009: taking root and branching out. Washington, DC, USA: Ecosystem Marketplace. 72 p.

9. Stanton, T., M. Echavarria, K. Hamilton, and C. Отt. 2010. State of watershed payments: an emerging marketplace. Washington, DC, USA: Ecosystem Marketplace. 102 p. 
10. Madsen, B., N. Carroll, and K. Moore Brands. 2010. State of biodiversity markets report: offset and compensation programs worldwide. Washington, DC, USA: Ecosystem Marketplace. 73 p.

11. Bohlen, P. J., S. Lynch, L. Shabman, M. Clark, S. Shukla, And H. Swain. 2009. Paying for environmental services from agricultural lands: an example from the northern Everglades. Frontiers in Ecology and the Environment 7:46-55.

12. Sargent-Michaud, J. 2009. A return on investment: the economic value of Colorado's conservation easements. Denver, CO, USA: Trust for Public Land. 8 p.

13. Dutilly-Diane, C., N. Mccarthy, F. Turkelboom, A. Bruggeman, J. Tiedemann, K. Street, and G. Serra. 2007. Could payments for environmental services improve rangeland management in Central Asia, West Asia and North Africa? Washington, DC, USA: International Food Policy Research Institute. CAPRI Working Paper No. 62.33 p.

14. PAlm, E. 2011. From forests to faucets. Headwaters. Denver, CO: Colorado Foundation for Water Education. p. 11-13.

15. Hanson, C., J. Ranganathan, C. Iceland, and J. Finisdore. 2008. Corporate ecosystem services review: guidelines for identifying business risks and opportunities arising from ecosystem change. Washington, DC, USA: World Resources Institute. $37 \mathrm{p}$.

16. Nutrition Business Journal. 2004. The OTA 2004 manufacturer survey overview. Available at: http://www.ota. com/pics/documents/2004SurveyOverview.pdf. Accessed 22 July 2010.

17. Zinden, S., and D. Lee. 2005. Paying for environmental services: an analysis of participation in Costa Rica's PSA program. World Development 33:255-272.

18. Mccauley, D. J. 2006. Selling out on nature. Nature 443:27-28.

19. Redford, K. H., and W. M. Adams. 2009. Payment for ecosystem services and the challenge of saving nature. Editorial. Conservation Biology 23:785-787.
20. Walker, S., A. L. Brower, R. T. T. Stephens, and W. G. LEe. 2009. Why bartering biodiversity fails. Conservation Letters 2:149-157.

21. Leopold, A. 1987. A Sand County almanac. New York, NY, USA: Oxford University Press. 228 p.

22. Sкroch, M., and L. Lopez-Hoffman. 2010. Saving nature under the big tent of ecosystem services: a response to Adams and Redford. Conservation Biology 24:325-327.

Authors are Assistant Professor, Dept of Human Dimensions of Natural Resources, Colorado State University, Fort Collins, CO 80523, USA, joshua.goldstein@colostate.edu (Goldstein); Graduate Student, School of Natural Resources and the Environment, University of Arizona, Tucson, AZ 85721, USA (Presnall); Assistant Professor, School of Natural Resources and the Environment, University of Arizona, Tucson, AZ 85721, USA (López-Hoffman); Research Social Scientist, The Southwest Center, University of Arizona, Tucson, AZ 85721, USA (Nabhan); Professor, Dept of Human Dimensions of Natural Resources, Colorado State University, Fort Collins, CO 80523, USA (Knight); Professor and Extension Specialist, School of Natural Resources and the Environment, University of Arizona, Tucson, AZ 85721, USA (Ruyle); and Rocky Mountain Regional Director, Center for Conservation Incentives, Environmental Defense Fund, Boulder, CO 80304, USA (Toombs). J.H.G. was funded in part by fellowships through the Warner College of Natural Resources and the Center for Collaborative Conservation at Colorado State University; C.K.P. was funded in part by a Springfield Fellowship and travel grant through University of Arizona's School of Natural Resources and the Environment; G.P.N. was funded by Invoking the Pause. 